\title{
Seroprevalence of Hepatitis B Virus Infection among an Afro- descendant Community in Brazil
}

\author{
Ana RC Motta-Castro, Clara FT Yoshida*/+, Elba RS Lemos*, Jaqueline M Oliveira*, \\ Rivaldo V Cunha, Lia L Lewis-Ximenez*, Pedro H Cabello*, Kátia MB Lima**, \\ Regina MB Martins***
}

\begin{abstract}
Hemonúcleo do Hospital Universitário, Universidade Federal de Mato Grosso do Sul, Campo Grande, MS, Brasil * Departamentos de Virologia e Genética, Instituto Oswaldo Cruz-Fiocruz, Av. Brasil 4365, 21045-900 Rio de Janeiro, RJ, Brasil **Coordenadoria de Imunizações, Secretaria de Saúde do Estado Mato Grosso do Sul, Campo Grande, MS, Brasil ***Instituto de Patologia Tropical e Saúde Pública, Universidade Federal de Goiânia, Goiânia, GO, Brasil

Furnas dos Dionísios is an Afro-Brazilian black community whose descendants were mainly fugitive slaves that established themselves in the State of Mato Grosso do Sul (MS), Brazil. The population is comprised mainly of low socioeconomic individuals who are engaged in agricultural activities. The objective of this study was to investigate the prevalence of hepatitis $B(H B)$ and its correlation with epidemiological data obtained from the community. The studied population totaled 260 individuals with ages varying from 1 to 79 years (median 20). One hundred thirtythree (51.2\%) were females and 127 (48.8\%) were males. A high prevalence for anti-HBc was observed (42.7\%), with present infection detected in $9.2 \%$ of the subjects who were also $H B$ surface antigens (HBs Ag) positive; $27.3 \%$ were anti-HBc and anti-HBs reactive, and $6.2 \%$ had anti-HBc as only marker. The prevalence for anti-HBc was proportional to age, reaching its highest peak in age categories greater than 50. No serological marker was detected in children under the age of 2 years, however anti-HBc was present in 12 subjects with ages between 2 and 14 years, of these $8(7.4 \%)$ were HBsAg positive. Among individuals over the age of 15 years, 99 were anti-HBc reactive, of these $16(10.5 \%)$ were also HBsAg positive, thus suggesting an increased prevalence of HBV carriers among children and adolescents. The risk factors observed in this community that were significantly associated with anti-HBc positivity were age (over 20 years) and having an anti-HBc positive mother. Both HBeAg and anti-HBe were detected in $44.4 \%$ of the samples tested. HBsAg subtypes found in the studied population were adw 2 (77.7\%) and ayw 2 (23.3\%). While intrafamilial transmission was most likely responsible for HBV infection among children, other routes such as sexual contact might be considered for individuals with ages over 15 years.
\end{abstract}

Key words: hepatitis B - Afro-descendants - seroprevalence - transmission - Brazil

Hepatitis B virus (HBV) is believed to infect more than 350 million individuals throughout the world and its prevalence varies widely in different geographic regions. The relationship between chronic HBV infection and cirrhosis/hepatocarcinoma has been presented by many authors, giving this infection an important cause of morbimortality and of major concern to public health (Kew 1998, Hilleman 2001).

Epidemiological studies carried out in different parts of the world show that the characteristics of the population, such as sanitary conditions, lifestyle, hygiene, risk and socioeconomic factors are related to large variations in the frequency and prevalence of HBV infection (Karim et al. 1991).

The HBsAg subtypes present typical geographic distribution that probably reflects the local of its origins and the migration of infected individuals. The HBsAg subtypes are important epidemiological markers to investigate the prevalence, transmission, and migration of HBV (Couroucé-Pauty \& Soulier 1983, Teles et al. 1999).

This study was supported by $\mathrm{CNPq}$ and Capes.

${ }^{+}$Corresponding author. Fax: +55-21-2270.6397. E-mail: yoshida@ioc.fiocruz.br

Received 5 April 2002

Accepted 25 September 2002
Africa, considered a region of high endemicity, owns the second greater number of chronically infected individuals with $\mathrm{HBV}$. Of an approximate 470 millions of people that live in that continent, more than 5 million are chronic carriers and about 12.5 will eventually die from hepatic illnesses induced by HBV, presenting a mortality risk of 25\% (Kiire 1996).

The importance of studying HBV infection in isolated Afro-descendant communities is based on the absence of epidemiological data on Afro-descendant populations in Brazil; the high prevalence of HBsAg in African countries (5 to 20\%); and the strong association between intrafamilial transmission of HBV and factors related to frequent and repeated exposure to the virus. Thus, the objectives of the present study were to investigate the prevalence of the HBV serological markers and the association of demographic variables and risk factors in the afro-descendant community of Furnas dos Dionísios, State of Mato Grosso do Sul (MS), Brazil. These findings may allow to obtain seroepidemiological data to aid in effective decisions for controlling and preventing HBV infection.

\section{CASUISTICS AND METHODS}

This study was conducted in the Afro-descendant community of Furnas dos Dionísios, founded in 1885 and pertaining to the District of Rio Verde and the city of 
Jaraguari, MS, which is located northward from Campo Grande, capital of the State of MS, Central Brazil.

A total of 430 Afro-descendants living in the community of Furnas dos Dionísios were invited to participate in the study, and $260(60.5 \%)$ individuals consented in participating. The study took place between October 1999 and March 2000 and these 260 participants were identified to belong to 64 families.

The population, in general, had low socioeconomic and educational levels, poor health conditions, and lacked sanitation and sewage disposal. The economy was based on subsistence agriculture.

A standardized form was used to collect data on individual characteristics and risk factors for HBV infection such as: history of sexually transmitted diseases (STD), multiple partners, condom use, household contacts with HBV infected subject, history of blood transfusion, dental treatment, surgery, acupuncture, tattoos, intravenous drug use and sharing razor blade.

Serological tests - Serum samples were tested by enzyme-linked immunosorbent assay (ELISA) to detect the following serological markers for HBV infection: hepatitis B surface antigen (HBsAg), antibodies against HBsAg (anti-HBs) and antibodies against hepatitis B core antigen (anti-HBc) (Hepanostika Organon Teknika B.V., Boxtel, Holland). HBsAg positive samples were further tested for IgM anti-HBc, hepatitis B e antigen ( $\mathrm{HBeAg}$ ) and antibodies against $\mathrm{HBeAg}$ (anti-HBe) (Hepanostika Uni-form Organon Teknika B.V.) and submitted to the determination of the HBsAg subtypes (Fiocruz, Brazil).

Data analysis - A descriptive analysis was performed by calculating means, medians and frequencies. Prevalence and 95\% confidence intervals (95\% CI) were calculated. Chi-squared test or Chi-square for trend test were performed to evaluate risk factors associated with HBV infection. Crude and adjusted odds ratio with $95 \% \mathrm{CI}$ were calculated to determine the strength of association between variables by uni and multivariate analysis using STATA 6 (State Corporation, College Station, Texas, USA).
Statistical significance was assessed at the 0.05 probability level in all analyses.

\section{RESULTS}

The ages of the study population varied from 1 to 79 years, with a mean age of 25 . More than $50 \%$ of the population consisted of individuals whose ages were less than 20 years. As for gender, $133(51.2 \%)$ were females and 127 $(48.8 \%)$ were males (Table I). This population did not differ in relation to age and gender $\left(\chi^{2}=14.72 ; p=0.257\right)$.

To assess the prevalence of HBV serological markers in the study community, 260 individuals were analyzed (Fig. 1). Anti-HBc, considered the most representative marker for HBV exposure, was detected in 111 individuals, resulting in $\mathrm{HBV}$ prevalence infection of $42.7 \%$ (CI $95 \%: 36.8-48.8$ ). All of these were negative for IgM anti$\mathrm{HBc}$, indicating the absence of acute or recent infection in this population. HBsAg was observed in $24(9.2 \%)$ subjects. Detection of both anti-HBc and anti-HBs was found

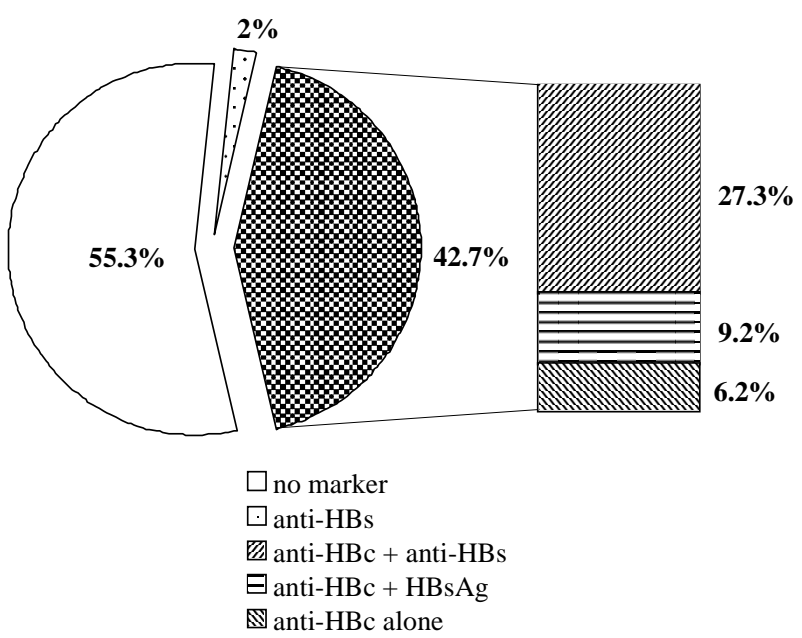

Fig. 1: hepatitis B virus (HBV) serological markers among Afrodescendants from Furnas dos Dionísios, Mato Grosso do Sul, Central Brazil, 1999/2000.

TABLE I

Age and sex distribution among Afro-descendants from Furnas dos Dionisios, Mato Grosso do Sul, Central Brazil, 1999/2000

\begin{tabular}{cccccccc}
\hline $\begin{array}{c}\text { Characteristics } \\
\text { Age (years) }\end{array}$ & $\mathrm{N}$ & $\%$ & $\mathrm{~N}$ & Female & Total & \multicolumn{2}{c}{$\begin{array}{c}\text { Acumulative total } \\
\%\end{array}$} \\
\hline $0-5$ & 20 & 62.5 & 12 & 37.5 & 32 & 12.3 & 12.3 \\
$6-10$ & 20 & 41.7 & 28 & 58.3 & 48 & 18.5 & 30.8 \\
$11-15$ & 14 & 46.7 & 16 & 53.3 & 30 & 11.5 & 42.3 \\
$16-20$ & 8 & 36.4 & 14 & 63.6 & 22 & 8.5 & 50.8 \\
$21-25$ & 11 & 68.7 & 5 & 31.3 & 16 & 6.2 & 57 \\
$26-30$ & 14 & 43.7 & 18 & 56.3 & 32 & 12.3 & 69.3 \\
$31-35$ & 8 & 66.7 & 4 & 33.3 & 12 & 4.6 & 73.9 \\
$36-40$ & 6 & 40 & 9 & 60 & 15 & 5.8 & 79.7 \\
$41-45$ & 6 & 46.2 & 7 & 53.8 & 13 & 5 & 84.7 \\
$46-50$ & 8 & 80 & 2 & 20 & 10 & 3.8 & 88.5 \\
$51-55$ & 3 & 37.5 & 5 & 62.5 & 8 & 3.1 & 91.6 \\
$56-60$ & 2 & 50 & 2 & 50 & 4 & 1.5 & 93.1 \\
\hline Total 127 & 7 & 38.9 & 11 & 61.1 & 18 & 6.9 & 100 \\
\hline
\end{tabular}

$\chi^{2}=14.7216 ; p=0.257$ 
in $71(27.3 \%)$ individuals, and suggests past infection with conferred immunity. Anti-HBc alone was detected in 16 $(6.2 \%)$ subjects. Only $2 \%$ of the subjects were previously vaccinated and were anti-HBs positive. The remaining population $(55.3 \%)$ lacked serological markers for HBV infection and was, thus, susceptible to HBV.

The Fig. 2 shows a progressive increase in prevalence of anti-HBc with age. The highest prevalence (100\%) was observed in ages 51 to 60 years, followed by a slight reduction (94.4\%) among those older than 60. A significant trend of anti-HBc positivity in relation to age was found in the study population $\left(\chi^{2}\right.$ for trend $=95.27$; $<<$ $0.001)$.

When the population was stratified in two age groups: 0-14 and 15-79 years old (Table II), anti-HBc was detected in 12 subjects under 14 years, of these $8(7.4 \%)$ were HBsAg positive. Among individuals over the age of 15 years, 99 were anti-HBc reactive, of these $16(10.5 \%)$ were HBsAg positive.

Serological tests for detecting $\mathrm{HBeAg}$ and anti-HBe markers were performed in $18(75 \%)$ of the $24 \mathrm{HBsAg}$ reactive serum samples, and a positivity of $44.4 \%$ was observed for each of these markers. Two $(11.2 \%)$ were negative for both markers.

In order to evaluate the HBV subtypes distribution among this Afro-descendant community, subtyping was performed on HBsAg positive samples. Eighteen of 24 (75\%) could be subtyped. Subtype adw $2(77.7 \%)$ was predominant, followed by ayw $2(22.3 \%)$.
Analysis of all risk factors studied showed that age over 20 years, history of STD, sexual contact with anti$\mathrm{HBc}$ positive partner, anti-HBc positive mother, previous blood transfusion, dental treatment and history of surgery were significantly associated with HBV seropositivity by univariate analysis (Table III). However, multivariate analysis revealed that only age over 20 years and having a seropositive mother were significantly associated with HBV infection in this population.

\section{DISCUSSION}

The present investigation showed an elevated prevalence $(42.7 \%)$ of HBV infection in Afro-descendants from Furnas dos Dionísios, MS, Central Brazil. This was lower than those observed in West Africa, where prevalence rates ranging from 56 to $98 \%$ were reported (Kiire 1996), but higher than that obtained in Gambia (33\%) (VallMayans et al. 1990). On the other hand, Tabor et al. (1985), while studying a population with similar characteristics of this investigation, found rates of 42 to $65 \%$ for $\mathrm{HBV}$ in five regions in Zambia, Africa. Nevertheless, there is no data in other Afro-Brazilian black communities to make a comparative analysis.

A significant trend of HBV seropositivity in relation to age was observed. The positivity for anti-HBc was low in 0 to 10 -year-old children and increased with age to a gradual and cumulative elevation. The highest prevalence $(100 \%)$ was seen in individuals between 51 and 60 years old.

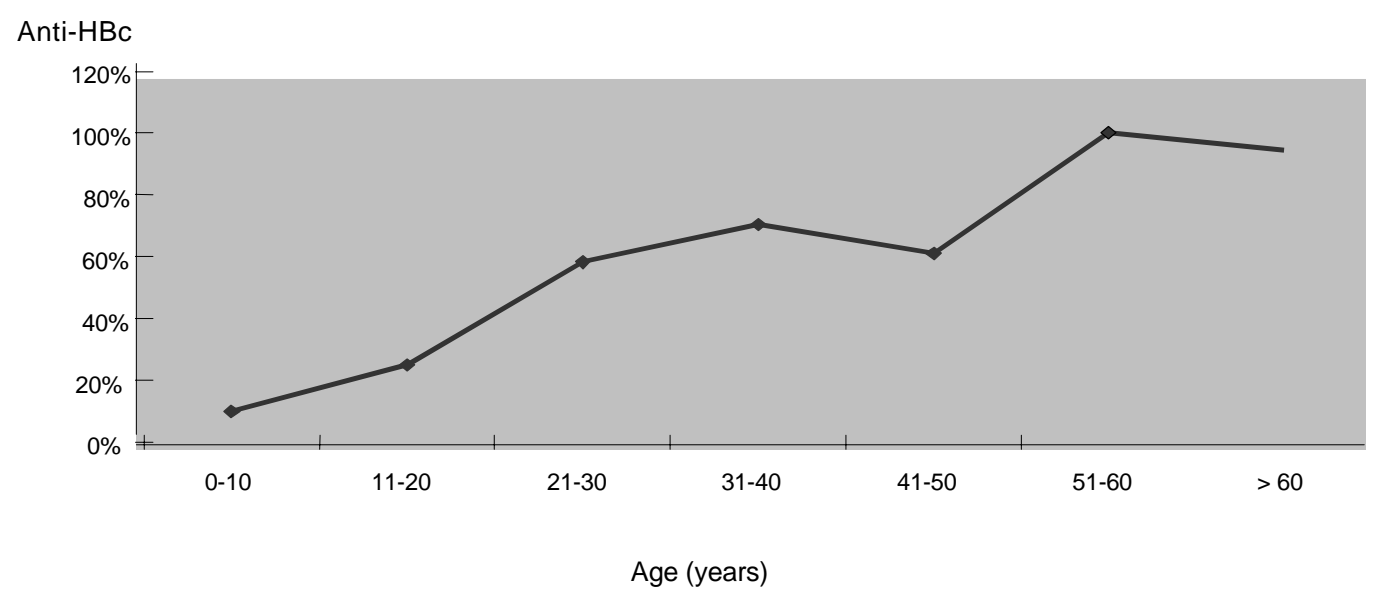

Fig. 2: anti-hepatitis B core $(\mathrm{HBc})$ positivity among Afro-descendants from Furnas dos Dionísios, Mato Grosso do Sul, Central Brazil, according to the age.

TABLE II

Prevalence of hepatitis B viral markers (HBsAg and anti-HBc) in Afro-descendants from Furnas dos Dionísios, Mato Grosso do Sul, Central Brazil, according with stratified ages, 1999/2000

\begin{tabular}{lccccr}
\hline Age (years) & $\mathrm{N}$ & Anti-HBc & Positive & HBsAg & \multicolumn{2}{c}{ Positive } \\
$\%$ & N & $\%$ & 8 & 7.4 \\
\hline $0-14$ & 108 & 12 & 11.1 & 16 & 10.5 \\
$15-79$ & 152 & 99 & 65.1 & 24 & 9.2
\end{tabular}

Anti-HBc: $\chi^{2}=72.3380 ; \mathrm{p}<0.0001 ; \mathrm{HBsAg}: \chi^{2}=0.5728 ; \mathrm{p}=0.449$ 
HBsAg, a marker which indicates present infection, was detected in $9.2 \%$ of the subjects. This suggests the area under study as a region of high endemicity. Similar findings (10 to 20\%) were reported in regions of high endemicity in Africa. Also, other studies showed elevated prevalence rates as 19\% in rural populations of Equatorial Africa (Richard-Lenoble et al. 1995), 9 to $20 \%$ in the adult population of Western Africa, and 14.6\% in Mozambique (Kiire 1996).

In addition, when the population under study was stratified in two age groups: $0-14$ and $15-79$ years old, a high prevalence for $\mathrm{HBsAg}(7.4 \%)$ was found in children and adolescents. According to Szmuness et al. (1973), HBsAg is rarely detected in children and adolescents in low endemic areas, differently from high endemic areas, where detection is frequent.

The determination of HBsAg subtypes has an important value as an epidemiological marker. Through subtypes, infection source can be identified and migratory chains can be analyzed (Couroucé-Pauty \& Soulier 1983, Gaspar \& Yoshida 1987, Teles 1999). In this study, subtypes were identified in $75 \%$ of the HBsAg positive samples, with a predominance of $\mathrm{adw}_{2}(77.7 \%)$ followed by ayw ${ }_{2}(22.3 \%) . \mathrm{Adw}_{2}$ was the most frequent HBsAg subtype found in Brazil and Africa (Couroucé-Pauty \& Soulier 1983, Gaspar \& Yoshida 1987). In addition, the detection of ayw ${ }_{2}$ subtype in HBsAg positive members of one family or $\mathrm{adw}_{2}$ in other three families suggests the intrafamilial transmission of HBV (date not shown).

Although the number of subjects under the age of 2 years was small, all of these were HBV seronegative (data not shown), the absence of HBV carriers in this age group strongly indicates horizontal transmission of the virus in this community. It is believed that the transmission of HBV is greatly influenced by social features (Martinson et al. 1998). In this investigation, the low socioeconomic level of the population, poor hygienic conditions, precarious household and clusters of individuals per habitation are characteristics that, probably, increased dissemination of HBV infection in this community. Similar sociodemographic characteristics were observed in a study of HBV intrafamilial transmission in the South Africa (Karim et al. 1991). Still in Africa, lower rates of HBsAg have been observed in children in urban areas when compared to those of the country. Rural areas may promote HBV infection due to the low socioeconomic status, the precarious personal hygiene with considerable chances of transmission through skin injuries with infected fluids, secretions and saliva, sharing personal objects (as razor blade and toothbrush), insects bites and so on (Kiire 1996). A study conduct in a town of the state of São Paulo, Brazil, in which risk factors were evaluated, showed that

TABLE III

Risk factors associated with hepatitis B virus (HBV) infection in Afro-descendants from Furnas dos Dionísios, Mato Grosso do Sul, Central Brazil, 1999/2000

\begin{tabular}{|c|c|c|c|c|}
\hline Risk factor & $\begin{array}{c}\text { HBV } \\
\text { Positive/Total }\end{array}$ & $\begin{array}{c}\text { Odds Ratio (95\% CI) } \\
(\%)\end{array}$ & Crude & Adjusted \\
\hline Age $>20$ years & $90 / 128$ & (70.3) & $13.5(7.4-24.4)$ & $13.5(7.4-24.7)$ \\
\hline \multicolumn{5}{|l|}{ STD } \\
\hline No & $81 / 134$ & $(60.4)$ & 1.0 & 1.0 \\
\hline Yes & $18 / 21$ & (85.7) & $4.1(1.1-14.5)$ & $3.7(0.9-13.9)$ \\
\hline \multicolumn{5}{|c|}{ HBV positive partner } \\
\hline No & $11 / 44$ & (25) & 1.0 & 1.0 \\
\hline Yes & $59 / 113$ & $(52.2)$ & $8.6(4.8-15.4)$ & $1.8(0.7-4.2)$ \\
\hline \multicolumn{5}{|c|}{ HBV positive mother } \\
\hline No & $2 / 11$ & $(18.2)$ & 1.0 & 1.0 \\
\hline Yes & $44 / 54$ & $(81.5)$ & $6.0(2.7-13.8)$ & $5.4(2.1-14.1)$ \\
\hline \multicolumn{5}{|c|}{ Blood transfusion } \\
\hline No & $103 / 243$ & (42.4) & 1.0 & 1.0 \\
\hline Yes & $8 / 10$ & $(80)$ & $5.6(1.2-27.1)$ & $1.6(0.3-8.8)$ \\
\hline \multicolumn{5}{|l|}{ Dental treatment } \\
\hline No & $62 / 178$ & $(34.8)$ & 10 & 1.0 \\
\hline \multirow{2}{*}{\multicolumn{5}{|c|}{ Sharing razor blade }} \\
\hline & & & & \\
\hline No & $89 / 142$ & $(62.7)$ & 1.0 & 1.0 \\
\hline Yes & $10 / 15$ & $(66.7)$ & $2.8(0.9-8.5)$ & $1.3(0.4-4.5)$ \\
\hline \multicolumn{5}{|c|}{ History of surgery } \\
\hline No & 79/194 & $(40.7)$ & 1.0 & 1.0 \\
\hline Yes & $32 / 53$ & $(60.4)$ & $2.1(1.1-4.0)$ & $0.7(0.3-1.6)$ \\
\hline \multicolumn{5}{|l|}{ Condom use } \\
\hline No & $81 / 129$ & $(62.8)$ & 1.0 & 1.0 \\
\hline Yes & $18 / 28$ & $(64.3)$ & $2.6(2.4-6.4)$ & $1.1(0.4-3.0)$ \\
\hline \multicolumn{5}{|l|}{ Male gender } \\
\hline No & $53 / 130$ & $(41.5)$ & 1.0 & 1.0 \\
\hline Yes & $57 / 125$ & (45.6) & $1.2(0.7-1.90)$ & $1.3(0.7-2.4)$ \\
\hline
\end{tabular}

STD: sexually transmited disease; CI: confidence interval 
individuals from rural areas with worse social conditions are at higher risk for HBV infection (Passos et al. 1993).

In addition, seroepidemiologic studies established that the transmission of HBV is relatively common between individuals and patients chronically infected that share the same household (Heathcote 1974, Hadziyannis 1975), or crowed living rooms, and have poor hygiene (Karim et al. 1991). According to Szumuness et al. (1973), serological evidences of intrafamilial transmission is greater in non-caucasian families and also depends on the size of the family and cluster of individuals in household.

The associations observed in the univariate analysis between positivity for anti-HBc and sexual contact with a seropositive partner for HBV, as well as history of STD, agree with the literature that has demonstrate the sexual transmission of the HBV (Rosenblum et al. 1992). Studies on heterosexual transmission of HBV demonstrated that Afro-descendants have a higher prevalence of HBV infection than Caucasian, and probably the virus is transmitted mainly through sexual contact (Alter et al. 1986). Parenteral exposure factors (history of blood transfusion, dental treatment and surgery procedures) also showed an association with HBV infection by univariate analysis. Although many studies have demonstrated that sharing of sharp objects is a risk factor for the HBV exposure (Vallmayans et al. 1990, Karim et al. 1991, Koff et al. 1997), sharing of razor blade was not significantly associated with HBV infection in the study population.

After the multivariate analysis, being over 20 years of age and having seropositive mother remained significantly associated with HBV infection. Individuals born to anti$\mathrm{HBc}$ seropositive mothers had a 5.4-fold (IC 95\%: 2.1-14.1) greater risk for HBV exposure than those born to anti$\mathrm{HBc}$ negative mothers, and suggests mother-to-infant transmission as an important role in this community. In spite of these findings, there were no positive child under 2 years of age and there were only two HBsAg positive mothers.

Although it was observed that the risk of HBV infection in subjects exposed to intrafamilial contact was greater among those whose mothers were seropositive, sexual transmission among individuals over the age of 15 years should not be discarded. In endemic regions, intrafamilial transmission of HBV has been shown to be an important route of the virus dissemination in households with low socioeconomic status (Karim et al. 1991, Passos et al. 1993).

We therefore conclude that elevated prevalence of HBV infection found in Furnas dos Dionísios suggests this region to be classified as one of high endemicity. Considering yet, the results obtained, preventive measures, such as educating and vaccinating the susceptible population are of fundamental importance to control HBV infection in this community and are presently being put into practice by Immunization Program of the Secretary of Health of the state of Mato Grosso do Sul.

\section{ACKNOWLEDGEMENTS}

To Cleber Ferreira Ginuino for collecting patient's samples and Marli Sidoni for performing HBsAg subtyping.

\section{REFERENCES}

Alter MJ, Ahtone J, Starko K, Weisfuse I, Vacalis TD, Maynard JE 1986. Hepatitis B virus transmission between heterosexuals. JAMA 256: 1307-1310.

Couroucé-Pauty AM, Soulier JP 1983. Distribution of HBsAg subtypes in the world. Vox Sang 27: 533-49.

Gaspar AMC, Yoshida CFT 1987. Geographic distribution of HBsAg subtypes in Brazil. Mem Inst Oswaldo Cruz 82: 253-258.

Hadziyannis SJ 1975. Non-parenteral transmission of viral hepatitis in Guinea. Am J Med Sci 270: 313-318.

Heathcote J, Gateau P, Sherlock S 1974. Role of the hepatitis B antigen carriers in non parenteral transmission of hepatitis B virus. Lancet 4: 370-372.

Hilleman MR 2001. Overview of the pathogenesis, prophylaxis and therapeutics of viral hepatitis $\mathrm{B}$, with focus on reduction to practical applications. Vaccine 19: 1837-1848.

Karim SA, Thejpal R, Coovadia H 1991. Household clustering and intra-household transmission patterns of hepatitis B virus infection in South Africa. Interl J Epidemiol 20: 495503.

Kew CM 1998. Hepatitis viruses and hepatocellular carcinoma. Res Virol 149: 257-262.

Kiire CF 1996. The epidemiology and prophylaxis of hepatitis $\mathrm{B}$ in Sub-Saharan Africa: a view from tropical and subtropical Africa. Gut 38 (Suppl. 2): S5-S12.

Koff RS, Slavin MM, Connelly LJD, Rosen DR 1997. Contagiousness of acute hepatitis B. Gastroenterology 72: 297300 .

Martinson FE, Weigle KA, Royce RA, Weber DJ, Suchindran CM, Lemon SM 1998. Risk factors for horizontal transmission of hepatitis B virus in a rural district in Ghana. Am $J$ Epidemiol 147: 478-487.

Passos ADC, Gomes UA, Figueiredo JFC, Nascimento MMP, Oliveira JM, Gaspar AMC, Yoshida CFT 1993. Influence of migration on prevalence of serological hepatitis B markers in a rural community. Analysis of prevalence by birthplace. Rev Saúde Pública 27: 30-35.

Richard-Lenoble D, Traore O, Kombila M, Roingeard P, Dubois F, Goudeau A 1995. Hepatitis B, C, D and E markers in rural Equatorial African villages (GABON). Am J Trop Med Hyg 53: 338-341.

Rosenblum L, Darrow W, Witte J, Cohen J, French J, Sikes K, Gill PS, Potterat J, Reich R, Hadler S 1992. Sexual practices in the transmission of hepatitis B virus and prevalence of hepatitis Delta virus infection in female prostitutes in the United States. JAMA 267: 2477-2481.

Szmuness W, Prince AM, Hirsh RL, Brotman B 1973. Familial clustering of hepatitis B infection. New England J Med 289: 1162-1166.

Tabor E, Bayley AC, Cairns J, Pelleu L, Gerety RJ 1985. Horizontal transmission of hepatitis B virus among children and adults in five rural villages in Zambia. J Med Virol 15: 113120.

Teles SA, Martins RMB, Vanderborght B, Stuyver L, Gaspar AMC, Yoshida CFT, 1999. Hepatitis B virus: genotypes and subtypes in Brazilian hemodialysis patients. Artif Organs 23: 1074-1078.

Vallmayans VM, Hall AJ, Inskip HM, Chotard J, Lindsay SW, Coromina E, Mendy M, Alonso PL, Whittle H 1990. Risk factors for transmission of hepatitis B virus to Gambian children. Lancet 336: 1107-1109. 